\title{
Barriers to US industrial biotechnology research consortia
}

\author{
Dale L. Oxender and C. Fred Fox
}

In 1986-1987, the research directors of major and medium-sized US biotechnology companies agreed on the wisdom of developing cooperative research arrangements in protein engineering, bioprocess and large-scale animal cell culture technologies. However, upper-level corporate managers were not convinced that collaborative approaches would be essential for the maintenance of longterm competitiveness of the US biotechnology industry. Now that cooperative research efforts in Japan and Europe are beginning to challenge US supremacy in biotechnology, the prospect of US industry consortia may be viewed in a kinder light. We believe that the US government has a key role to play in providing both financial and logistical support.

During 1986-1987 we invited research directors from several dozen major biotechnology companies to explore benefits that might be derived from consortia conducting joint research on problems they identified as common barriers to achieving marketable products. The structure of the consortium was to be developed by the participating members. A brief account of these activities appeared earlier ${ }^{1}$. At that time, one of us (DLO) had recently concluded a report for US governmental agencies on Japanese activities in the field of biotechnology (JTECH Report) ${ }^{2}$; the other (CFF) was (and is) Director of the UCLA Symposia on Molecular and Cellular Biology. In parallel with the meeting of corporate research directors, sixty members of university research establishments and governmental agencies also met (at the Keystone Center, Keystone, Colorado) to examine substantive policy issues and possible roles for public sector scientists.

D. L. Oxender is at the Center for Molecular Genetics, $5319 \mathrm{Med}$. Sci. I, 0606, University of Michigan, Ann Arbor, Michigan 48109. USA. C. F. Fox is at the UCLA Symposia Office, 2032 Armacost Ave., Los Angeles, CA 90025.
These early meetings concentrated on identifying technologies that limit commercialization of new biotechnology products. A list of limiting technologies was initially created from extensive input from the corporations. The consensus view was that protein engineering, large-scale animal cell culture, and bioprocessing were major obstacles to product development. Protein engineering emerged as the most likely candidate for a consortium, the objective of which would be cooperative development of improved technologies for producing altered or novel proteins with commercial value.

There was general agreement that problems such as determining the rules governing protein folding would be more likely to yield to cooperative than to individual efforts. However, few of the companies were prepared to tackle the problems inherent in creating cooperative research consortia without greater incentives from the US government. Around the same time and on several occasions, the concept of an industry-driven cooperative research arrangement was on the agenda of the Pharmaceutical Manufacturers' Association (PMA) research committee; the outcome was similarly inconclusive.

It should be noted that, for the most part, the corporate research directors were receptive and optimistic about research consortia and worked hard to develop a feasible plan. It became increasingly clear, however, that when they took this idea back to their corporate directors, for a variety of reasons, the corporations were not yet prepared to tackle the problem.

\section{What were the barriers to a consortium?}

Ron Cape, chairman of Cetus Corp. was quoted as saying 'There's an accumulation of detailed reasons at the nitty-gritty level that present quite a formidable barrier' to the development of a research consortium $^{1}$. These included corporate concern over patent rights, proprietary control and anti-trust regulations. There was also no agreement on which proteins were appropriate subjects for generic research. Additional concerns which surfaced during discussion included:

- corporate preferences for tackling smaller parts of a problem and owning the solution outright;

- the perception that milestones set by a common organizational structure would stifle research essential to a member's continued interest;

- the feeling that larger, established companies would derive less benefit than smaller firms (the consortium would contribute proportionally less to the company's overall research effort);

- companies close to the consortium site might benefit more;

- the best corporate scientists might be retained for in-house work rather than released to the consortium;

- significant organizational support and funding are unavailable from government;

- there are no good models to emulate (cultural differences may preclude direct comparisons with successful Japanese initiatives).

\section{Protein engineering consortia} outside the US

US dominance of biotechnology research has been eroded substantially by research efforts in Japan ${ }^{2}$ 
and Western Europe. This may reflect changes in funding for biotechnology research; this increased by $50 \%$ in Western Europe and 68\% in Japan from 1986 to 1987 , but by only $19 \%$ in the US. Past US experiences in the automobile and semiconductor industries show that a sizable technological lead can vanish rapidly.

\section{Japan's Protein Engineering Research Institute}

MITI, the Japanese government Ministry of International Trade and Industry, plays a key role in mediating transfer of technology to the market place. In April 1986, MITI catalysed the formation of the Protein Engineering Research Institute (PERI $^{3}$, a 14-company consortium which recently moved into new quarters near Osaka. Approximately $\$ 100$ million has been committed to PERI by the government and the companies over a 10-year period and member firms send scientists to engage in cooperative research at PERI for periods of 3-5 years. The aim of PERI is to enhance the ability to design novel proteins with medical or biotechnological applications. PERI is organized into the following five research departments:

- determination of three-dimensional protein structure;

- structure prediction and design using molecular dynamic analysis and computer modelling;

- protein remodelling through sitedirected mutagenesis and expression optimization for large-scale production;

- large-scale protein purification;

- development and management of computer databases and specialized software.

In PERI, the Japanese are addressing the same high-priority list of technologies upon which US biotechnology research companies reached consensus independently in our initiative. Any new technology developed by PERI is available to all 14 companies for their proprietary protein and peptide products, and patents are held by the consortium and licensed semi-exclusively to the member firms. The US commitment to protein engineering is certainly there; many companies have made substantial investments. However, in the standard (current) US approach, each company will develop each aspect of technology independently; repeated reinvention of the wheel Thus, in each company, major resources will be committed to develop, for instance, the software and computer systems for a first-class computational chemistry facility for macromolecular modelling and database management. Clearly, there would be advantages in sharing such a facility.

In October 1986, the government agency JDRC (the Research Development Corporation of Japan), created the High Technology Consortium System (HTCS) ${ }^{4}$. This was to systematically exploit the basic research generated in the ERATO (Exploratory Research for Advanced Technology) program $^{5}$ launched by JRDC in $1981^{3}$. The HTCS also plans to initiate other consortia to develop intellectual property emerging from national research laboratories, universities and other government research organizations.

US academic institutions are seldom effective in licensing their patented technologies, and substantial efforts may be required to overcome this barrier. Some university patent and licensing offices, (e.g. Stanford's) have been highly effective and might serve as models for other institutions.

\section{The UK Protein Engineering 'Club'}

In 1985, the UK's Biotechnology Directorate of the Science and Engineering Research Council (SERC) and four British companies launched the Protein Engineering 'Club'ti, This club supports research initiatives at universities with around a third of the funds coming from the com panies. SERC has also formed a similar club to support university research in animal cell physiology. These efforts provide a mechanism for industrial support of university research. In return, the companies have a 'hotline' to the results of leading researchers which should improve the transfer of technology for commercial product development.

\section{Can US ind ustry adopt these models?}

Many US pharmaceutical corporations take the view that Japan's effectiveness with research consortia such as PERI is the property of a unique cultural background. While the role of culture in cooperative research may be significant, it is difficult to evaluate. We cannot conclude that cultural differences between Japan or the UK and the US preclude development of a style of effective consortium unique to the US.

Direct roles for government agencies

The most obvious missing ingredient in our attempts to catalyse development of research consortia was government participation. In our early discussions, the idea of including governmental agencies was discussed, but rejected by several corporate representatives on the grounds that administration and decision-making ability of a consortium would be hampered by bureaucracy.

Examination of model consortia formed in Japan and England revealed two important roles for government. In each case, a government agency provided the leadership necessary for coordinating and catalysing the organization of the consortium and, equally if not more important, up to $70 \%$ of the initial financing.

\section{Long-range objectives}

The support and stability afforded by government participation is vital to consortia developing technologies such as protein engineering because the objectives are on a more distant horizon than those normally perceived by US firms. While US corporations generally limit their business plans to $3-5$ years, it is not uncommon for Japanese firms to look 10 years or so into the future. Japanese business has accurately assessed future markets in the automotive and electronics industries. There is no reason to believe that they are off the mark in targeting protein engineering as a key technology for commercializing biotechnology. 


\section{US corporation cooperative efforts outside biotechnology}

Therese Welter's article ${ }^{7}$ contains a comprehensive record of cooperative efforts in US research consortia such as the Microelectronics and Computer Technology Corp. (MCC), Semiconductor Research Corp. (SRG), National Center for Manufacturing Sciences, Bell Communications Research and Sematech. Each of these consortia was initiated largely in response to penetration of once secure US markets by other countries. Have these consortia been effective? They have certainly generated products. For instance, in April 1985 (earlier than expected), MCC announced their Proteus computer program for developing expert systems; consequently, Honeywell Information Systems, Inc. developed an expert system to design and place components on a circuit board. Boeing Electronics has established four laboratories to support MCCtransferred technologies.

The existing consortia also appear to dispel the myth that companies with huge in-house efforts benefit less than those without'. Quite the reverse; corporations with the largest internal commitment are clearly in the best position to take advantage of new technologies and transfer them rapidly to the market place.

\section{New research approaches for biotechnology}

Biology now has the tools to attempt major projects such as the mapping and sequencing of the Human Genome ${ }^{8}$. These projects will require an organized interdisciplinary approach with major resource commitments. One of the first steps in this approach will be gaining experience on smaller projects, such as sequencing the smaller genomes of $E$. coli and then yeast.

The conventional US approach to research funding is to make competitive grants available for supporting the best proposals. This may not be appropriate as a mechanism for funding genome sequencing. In Japan, a cooperative research approach has already been implemented, coordinated and directed by a government agency. Thus, a library of DNA fragments covering the $E$. coli chromosome has been divided among thirty universities, and each has been assigned the sequencing of a separate portion. The completed sequence of $E$. coli may soon be available from Japan.

Some current problems in biology, notably those of a broad and shallow nature, can benefit from an organized cooperative approach. These should complement rather than replace individual investigator-initiated (narrow and deep) research projects. It will be increasingly important in the future for the US to identify the right mix between these types of projects. It is precisely this dilemma that is associated with the huge resource commitments required for 'Big Science' projects. The US desperately needs to develop a sound and positive National Science Policy to meet this challenge.

\section{National science policy}

In our efforts to catalyse the formation of US biotechnology consortia, we did not find that the US government was prepared to play a highly active role in direct support of biotechnology commercialization in the US. This is in striking contrast to initiatives already under way in Japan, the UK and elsewhere. It is clear that the US government could play a more direct role in the development and commercialization of technology. We propose that the US government takes immediate steps to develop a rational, coherent National Science Policy by forming a high level agency specifically assigned that task. This agency should complement the highly successful individual projects with coordinated efforts directed at the development of new and improved capabilities in areas where the current level of technology is limiting progress. It should also catalyse industry input to develop consensus views on technology development requirements and coordinate both public and private sector efforts to meet these challenges.

We can no longer ignore the messages of Roy and Shapley in 'Lost at the Frontier', our science policy has been too long adrift like a vessel at sea with no captain. Now that pressure is being increased, the idea of forming US cooperative research consortia to meet generic research needs has become more attractive. An effective National Science Policy will meet this issue head-on by creating means to enable private and public sector scientists jointly to identify essential research endpoints and subscribe to research plans that achieve them expeditiously.

\section{References}

1 Greene, S. (1988) The Scientist 2,

2 Japanese Technology Evaluation Program (1985) JTECH Panel Report on Biotechnology in Japan, US Dept of Commerce

3 Martin, C. C. (1989) Genetic Engineering News 9, 10

4 High Technology Consortium System (1986) in Science and Technology in Japan 5, No. 17, 40

5 Japanese Technology Evaluation Program (1988) JTECH Panel Report on the Japanese (ERATO) Program, US Dept of Commerce

6 Anon. (1985) Biobulletin (Newsletter of SERC's Biotechnology Directorate) Vol. 2, No. 1, SERC

7 Welter, T. R. (1987) Industry Week July, 50-53

8 Fox, J. L. (1989) Bioi'Technology 7, 223-226

9 Shapley, D. and Roy, R. (1985) Lost at the Frontier, ISI Press

\section{Trends in Biotechnology}

Next month's issue includes the following articles

Features

- Patents as nontarif trade bartiers by Arthur G Cook lnstitute for the Future, Calfornia)

- Agricultural biotechnology in devefoping countfies effects of legal trends by John Barton (Stanford Law School)

Reviews

- Live recombinant vaccines for poultry by Ahn Finkelstein and Robert F Silva USDA Agricultural Research Service USA

- Gene transfer to cereals state of the an by lngo Potrykus lhstitute of Crop Sciences, ZuFich 